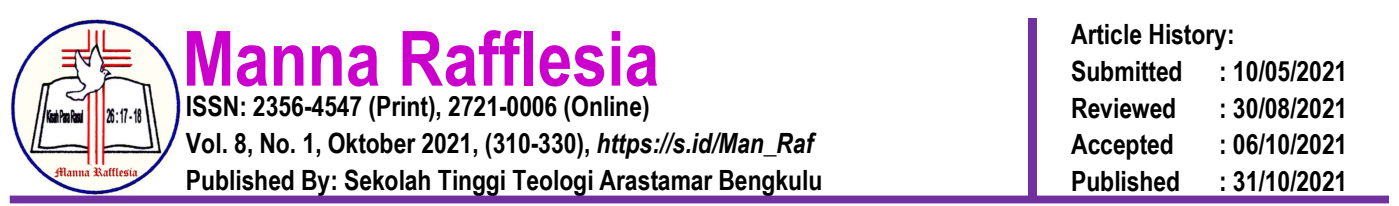

\title{
KONSEP TEOLOGI KEKUDUSAN SEORANG HAMBA TUHAN MENURUT JOHN CHRYSOSTOM
}

\author{
Fransisca Juliwati $\left.{ }^{1}{ }^{*}\right)$, Hendi $^{2}$ \\ Sekolah Tinggi Teologi Soteria Purwokerto ${ }^{12}$ \\ *)Email Correspondence:siskafransiska854@gmail.com
}

\begin{abstract}
The holiness of a priest is an important review in this paper based on the study of the text in the book entitled Six Books on the Priesthood written by John Chrysostom. A book dealing with the priesthood. The holiness of life is not only seen from one aspect, but there are three things that must be considered both in the position as a representative of Christ, in shepherding and spiritual growth through spiritual discipline. This article has used literature reasearch method, specific the thouht of John Chrysostom. The result of that is an priest has a very noble job despite many difficulties and temptations. Only the priest is qualified to bring offerings to God on a holy (intermediary) altar. The priest is not only responsible for his status as a representative of Christ (church confirmation) but must lead Christ's sheep to salvation even if his own life is at stake. Grace and mercy as well as an intimate relationship with God will further purify the heart, soul and mind of a priest so that through the spiritual discipline he does (prayer and repentance) more and more reflect Christ in his life, including his pastorate.
\end{abstract}

Keywords : John Chrysostom, Holiness, Servant of God.

Abstrak: $\quad$ Kekudusan seorang Imam merupakan ulasan penting dalam tulisan ini berdasarkan kajian teks dalam buku yang berjudul Six Books on the priesthood yang ditulis oleh John Chrysostom. Sebuah buku yang membahas mengenai keimamatan. Kekudusan hidup tidak hanya dilihat dari satu aspek saja melainkan ada tiga hal yang harus diperhatikan baik dalam jabatannya sebagai wakil Kristus, dalam penggembalaan maupun pertumbuhan spiritual melalui disiplin rohani. Penulisan ini menerapkan metode studi literatur secara khusus pemikiran teologis John Chrysostom. Hasil penelitian ini adalah seorang Imam memiliki tanggung jawab yang sangat mulia meskipun banyak kesulitan, hanya Imam yang dilayakkan membawa persembahan kepada Allah di atas altar yang kudus (perantara). Imam tidak hanya bertanggung jawab atas statusnya sebagai wakil Kristus saja melainkan harus menuntun dombadomba Kristus kepada keselamatan bahkan nyawanya sendiri menjadi taruhannya. Anugerah dan belas kasihan serta relasi yang intim dengan Allah merupakan kunci utama untuk semakin memurnikan hati jiwa dan pikiran seorang imam sehingga melalui disiplin rohani yang Ia kerjakan (doa dan pertobatan) semakin mencerminkan kristus dalam kehidupannya bahkan penggembalaannya.

Kata kunci : John Chrysostom, Kekudusan, Hamba Tuhan.

\section{PENDAHULUAN}

Sebuah buku kerohanian mengenai keimamatan yang ditulis oleh John

Chrysostom (347-407 M) salah satunya membahas tentang kekudusan seorang 
hamba Tuhan, buku Six Books on the Priesthood ini sangat penting bagi para hamba Tuhan pada masa kini, karena menerapkan cara penggembalaan/pelayanan yang sesuai dengan ajaran Yesus. Problem banyak hamba Tuhan masa kini ialah banyak yang melayani lebih mementingkan ambisi, mencari keuntungan untuk diri sendiri dan mengesampingkan pentingnya kekudusan hidup. Chrysostom menegaskan bahwa para imam memiliki sebuah jabatan yang kudus dan mulia, karena itu ambisi hamba Tuhan akan diuji dalam karakter dan spiritual, maka hendaknya jabatan imam perlu dilakukan dengan penuh tanggung jawab. ${ }^{1}$ Astin menuliskan bahwa seorang hamba Tuhan sangat berperan penting dalam pelayanan di gereja, khususnya dalam pertumbuhan dan perkembangan iman jemaat yang digembalakan. ${ }^{2}$ Untuk itu peran sebagai hamba Tuhan bukan sekedar jabatan, namun ada tanggung jawab untuk menggembalakan jemaat Kristus.

Gereja sangat berperan penting dalam menentukan atau memilih para calon hamba Tuhan, tentunya dengan dasar nilai-nilai kebenaran firman Tuhan sehingga tidak terdapat kekeliruan. Sebuah gereja tentunya memiliki kriteria dan standar tersendiri dalam menentukan calon hamba Tuhan. Namun tidak sedikit gereja saat ini, yang kurang menerapkan nilai-nilai atau prinsip dalam menentukan para calon hamba Tuhan, karena mengikuti dan terpengaruh perkembangan zaman. Hal tersebut menimbulkan akibat hadirnya ketidakselarasan. Eka Nur Cahyani dan Hendi menuliskan bahwa banyak gereja yang bergeser dari terminologi keimamatan dan telah mengusulkan prinsip lain

1 Graham Neville, "John Chrysostom: Six books on the priesthood," 1964, 1-50.

2 Astin Mangean, "Pendekatan Historis Kristis Terhadap Bilangan 3 dan 4 tentang Tanggung Jawab Pendeta," BIA': Jurnal Teologi dan Pendidikan Kristen Kontekstual 2, no. 2 (2019): 209, https://doi.org/10.34307/b.v2i2.133. 
dalam menyeleksi calon Imam/hamba Tuhan, ${ }^{3}$ seharusnya gereja memberikan syarat kualifikasi khusus dalam menyeleksi calon hamba Tuhan sesuai dengan standar dan kriteria yang telah ditentukan dalam organisasi sebuah gereja. Karena pekerjaan seorang Imam sangat mulia.

Chrysostom menegaskan bahwa calon hamba Tuhan harus memenuhi syarat/kualifikasi tertentu dalam memenuhi panggilan sebagai hamba Tuhan. Kekudusan hidup merupakan syarat penting yang perlu dimiliki seorang yang terpanggil menjadi hamba Tuhan. Seseorang yang ingin menjadi hamba Tuhan/Imam maka perlu benar-benar menguji kemurnian hati, pikiran dan jiwa. Mengandalkan pertolongan Roh Kudus untuk melewati setiap tantangan, godaan dan penderitaan. Seperti yang dialami Kristus yang menderita untuk menuju kemuliaan. Oleh karena itu tidak mudah menentukan calon hamba Tuhan, karena penilaian tidak hanya dari gereja, tetapi juga kesiapan calon hamba Tuhan dalam menjaga kekudusan hidup.

Chrysostom mengatakan bahwa Imam sebagai wakil Kristus dikhususkan untuk mewakili pelayanan malaikat di bumi dengan tuntunan Roh Kudus. Oleh sebab itu Chrysostom sangat menekankan bahwa jabatan seorang hamba Tuhan tidak hanya di dunia, melainkan apa yang dikerjakan di dunia merefleksikan apa yang dikerjakan di surga, segala tata cara ibadah di dunia merefleksikan tata cara di surga. Seorang Imam/Hamba Tuhan menjadi sorotan dan panutan jemaat yang digembalakan, bahkan dalam hal praktis yang sederhana. Oleh karena itu mengapa kehidupan seorang hamba Tuhan perlu selaras dan seimbang baik dalam pelayanan maupun kehidupan sehari-hari.

3 Eka Nur Cahyani dan Hendi Hendi, "Kemuliaan Jabatan Seorang Imam Menurut John Chrysostom," Fidei: Jurnal Teologi Sistematika dan Praktika 4, no. 1 (2021): 99, https://doi.org/10.34081/fidei.v4i1.171. 
Santoso menuliskan bahwa pengaruh yang berdampak dalam pelayanan seorang hamba Tuhan ketika menggembalakan jemaat adalah berani memposisikan diri antara ajaran yang diberikan kepada jemaat selaras dengan tindakan nyata yang diperlihatkan, yaitu teladan hidup. ${ }^{4}$ Selanjutnya Deswita menegaskan bahwa jiwa-jiwa yang digembalakan seorang hamba Tuhan perlu senantiasa diperlengkapi dengan kebenaran firman Tuhan sebagai dasar dan penopang iman. ${ }^{5}$ Chrysostom juga mengatakan bahwa seorang hamba Tuhan/Imam perlu mengetahui setiap karakter dari domba-domba yang digembalakan dan memulihkan rohani yang sakit. Dengan demikian kehidupan seorang hamba Tuhan perlu memiliki relasi yang melibatkan dan memprioritaskan Tuhan, serta senantiasa meminta tuntunan Roh Kudus. Sehingga selalu siap sedia dalam menjalankan tugas pelayanan, meskipun diperhadapkan dengan berbagai macam kesulitan, hambatan dan godaan lainnya.

Kekudusan hamba Tuhan sebagai wakil Kristus di dunia tidak hanya jabatan, melainkan perlu dinyatakan melalui tindakan menggembalakan dombadomba Kristus sesuai kehendak-Nya dengan tujuan memuliakan Allah. Peter Anggu menuliskan bahwa kedewasaan spiritual sangat penting dan menjadi prioritas atau syarat utama yang perlu dimiliki seorang hamba Tuhan, yang di dalamnya termasuk kekudusan. ${ }^{6}$ Chrysostom mengatakan bahwa kehidupan spiritual dan jasmani seorang imam juga menentukan penggembalaan, karena

\footnotetext{
4 Dwi Setio Budiono Santoso, "Peran Khotbah Gembala Sidang dalam Pertumbuhan Rohani Jemaat," MAGNUM OPUS: Jurnal Teologi dan Kepemimpinan Kristen 1, no. 2 (2020): 88, https://doi.org/10.52220/magnum.v1i2.39.

5 Deswita S Jihole, "MAKNA KEMULIAAN SEORANG IMAM MENURUT Artikel ini adalah sebuah ulasan mengenai makna kemuliaan seorang imam menurut pandangan Yohanes Krisostomus dalam bukunya yang berjudul Six Books on the Priesthood . Yaitu sebuah buku spiritual yang ditulis sendiri ol" 4, no. 2 (2020): 70-83.

6 Peter Anggu, "Pertumbuhan Karakter Kristen 'Kepribadian Seorang Pelayan," Jurnal Jaffray 3, no. 1 (2005): 26, https://doi.org/10.25278/jj71.v3i1.138.
} 
tanggung jawab hamba Tuhan sangat besar yaitu menggembalakan domba-domba Kristus yang telah ditebus oleh nyawa dan darah-Nya. Oleh sebab itu kekudusan hidup penting dimiliki oleh seorang Imam baik dalam jabatan, penggembalaan dan juga pertumbuhan spiritual melalui kedisiplinan rohani seorang Imam melatih, mengontrol dan memurnikan keinginan serta kehendaknya, sehingga layak sebagai wakil Kristus.

\section{METODE}

Dalam penulisan ini penulis menggunakan metode penelitian pustaka $^{7}$ yaitu mengkaji dari teks yang ditulis oleh John Chrysostom berdasarkan buku Six Books on the Priesthood sebagai landasan teori yang membahas mengenai keimamatan atau kehidupan seorang imam yang kita kenal sekarang dengan sebutan Gembala/Pendeta. ${ }^{8}$ Penulis juga berinteraksi dengan beberapa teks kitab suci, dan buku serta artikel jurnal yang berkaitan dengan pembahasan. Dan topik yang Penulis paparkan adalah mengenai sebuah tema yang jarang dipublikasikan yaitu pentingnya sebuah kekudusan bagi seorang hamba Tuhan dalam penggembalaannya berdasarkan pandangan John Chrysostom. Penelitian ini tidak memfokuskan pada penjelasan secara detail tentang kekudusan secara Alkitabiah seperti tulisan Roy Charly H.P. Sipahutar tentang revitalisasi dan arti kekudusan pelayan Kristen dari kaca mata Perjanjian Lama dan Perjanjian Baru. ${ }^{9}$ Penelitian ini fokus menguraikan konsep kekudusan secara praktis menurut pandangan

7 Handi Hadiwitanto, "Metode Kuantitatif dalam Teologi Praktis," GEMA TEOLOGIKA 2, no. 1 (28 April 2017): 1, https://doi.org/10.21460/gema.2017.21.291. Bdg. Leon Abdillah, "Bahan dan Metode Artikel IImiah (Material and Methods of Scientific Articles)," Menulis Artikel Ilmiah untuk Publikasi (Writing Scientific Papers for Publications). Medan: Yayasan Kita Menulis, 2020.x

8 Sonny Zaluchu, "Penderitaan Kristus Sebagai Wujud Solidaritas Allah Kepada Manusia," DUNAMIS: Jurnal Penelitian Teologi dan Pendidikan Kristiani 2, no. 1 (4 November 2017): 61, https://doi.org/10.30648/dun.v2i1.129. 2 (2018): 2.

9 Roy Charly H.P. Sipahutar, "REVITALISASI KEKUDUSAN DALAM HIDUP PELAYAN KRISTEN" 
Chrysostom dalam buku keimamatan yang mencakup 3 hal yaitu: Pertama, kekudusan dalam jabatan sebagai wakil Kristus. Kedua, Kekudusan dalam menggembalakan domba-domba Kristus. Ketiga, Memelihara kekudusan hidup melalui disiplin rohani.

\section{HASIL}

Kekudusan adalah salah satu ciri khas dari sifat utama Kristus (Im. 19: 2 dan Luk. 1: 49). Sebagaimana Yesus adalah kudus maka pelayan Tuhan ditekankan agar hidup kudus, karena mereka adalah wakil Kristus di bumi. Hasil penelitian ini menunjukkan bahwa hamba Tuhan yang hidup kudus berarti memiliki hubungan yang intim dengan Kristus Yesus. Dimana hidup kudus ini berarti hidup yang suci dan murni dihadapan Allah. Selanjutnya penelitian ini menghasilkan konsep kekudusan hidup seorang hamba Tuhan mencerminkan ciri khas atau karakter Kristus yang adalah kudus. Karena itu sebagai pelayan atau hamba Tuhan ditekankan perlu membereskan secara dosa yang telah dilakukan. Penelitian ini juga menghasilkan konsep bahwa proses membereskan dosa dapat dilakukan hanya datang menghampiri Kristus dengan menjalankan disiplin rohani yaitu pertobatan disertai dengan air mata, artinya ada sebuah penyesalan yang sangat dalam sehingga butuh belas kasihan Tuhan dan doa puja Yesus yang berarti meminta belas kasihan Tuhan. Dua disiplin rohani itulah yang dihasilkan dalam penelitian ini yang berguna bagi seorang hamba Tuhan, sehingga bisa melayani domba Kristus dan menjadi teladan bagi jemaat yang digembalakan.

\section{PEMBAHASAN}

Chrysostom menekankan pentingnya kekudusan bagi hamba Tuhan, melalui pemikiran Chrysostom ada tiga pokok teologis penting terkait kekudusan 
seorang hamba Tuhan yaitu memelihara kekudusan hidup melalui disiplin rohani, kekudusan dalam menggembalakan domba kristus dan kekudusan dalam jabatan sebagai wakil kristus

\section{Kekudusan Dalam Jabatan Sebagai Wakil Kristus}

Chrysostom menekankan bahwa imam tidak hanya sekedar jabatan biasa, karena seorang imam sebagai wakil Kristus yang mulia dan dikhususkan untuk menggembalakan domba-domba Kristus yang telah diselamatkan. Jabatan Imam tidak diberikan kepada orang-orang khusus yang dipilih oleh Kristus. Seorang Imam dituntut hidup dalam kekudusan karena jabatan yang dipikul merupakan jabatan kudus, selanjutnya seorang imam juga menjadi seorang gembala yang perlu menjaga, memelihara dan bertanggungjawab terhadap kehidupan dombadomba Kristus yang digembalakan. Chrysostom mengatakan bahwa tanggung jawab seorang Imam lebih lebih besar dibandingkan tanggung jawab orang tua, karena orang tua telah menghadirkan dan menyelamatkan secara jasmani, sedangkan Imam diberikan kuasa untuk menuntut orang percaya kepada pertobatan, sehingga ikut ambil bagian sebagai anak-anak Allah serta dilayakkan memiliki kehidupan kekal bersama-sama dengan Bapa dalam kekekalan.

Seorang Imam sebagai wakil Kristus dituntut hidup dalam kekudusan sebab Kristus adalah kudus, serta memiliki tekad dan kesanggupan untuk menjalankan panggilan yang mulia sebagai hamba Tuhan. Gerald O'Collins, SJ dan Michael Keenan Jones menuliskan bahwa dalam setiap kegiatan pelayanan yang dikerjakan oleh seorang hamba Tuhan/Pendeta akan menjadi sorotan bagi banyak orang, khususnya bagi jiwa-jiwa yang digembalakan. Karena itu kedewasaan spiritual seorang hamba Tuhan sangat diperlukan, khususnya dalam 
menjaga kekudusan. ${ }^{10}$ Seorang hamba Tuhan yang dipilih menjadi wakil Kristus di bumi perlu mengutamakan kehidupan spiritualitas dengan melakukan disiplin rohani melalui tuntunan Roh Kudus, sehingga memiliki kehidupan yang semakin kudus di dalam Tuhan. Soza menuliskan bahwa kekudusan tidak bisa dilihat dari segi moralitas yang tampak dari luar saja, melainkan ada sesuatu yang berperan didalamnya yaitu dianoia. ${ }^{11}$ Selanjutnya Valentino menegaskan untuk mencapai kekudusan seseorang harus mengupayakan diri untuk terus menerus hidup menyerupai sang pencipta (secara karakter), sehingga layak dalam menjalankan tugas sebagai pelayan sakramen di gereja. ${ }^{12}$ Oleh sebab itu, kekudusan hidup yang sesungguhnya adalah secara jasmani maupun rohani perlu diperlengkapi, dengan didasarkan pada kebenaran Alkitab (Ef. 4: 24; Luk. 1: 75: 1Tes 4: 1-12).

Chrysostom menuliskan bahwa seorang Imam perlu senantiasa mensucikan dan memurnikan hidup, karena tidak menjalankan pelayanan yang bernilai duniawi, melainkan terlibat dalam sakramen bernilai sorgawi sebagai imamat yaitu perantara (wakil Kristus) antara Allah dengan umat-Nya. Imam layak mempersembahkan korban kepada Allah di atas altar yang kudus, serta sakramen lain salah satunya perjamuan kudus. Hal tersebut yang membuat seorang Imam dihormati dan disegani. Dengan demikian jabatan seorang Imam merupakan jabatan yang mulia dan kudus, oleh sebab itu seorang Imam senantiasa memelihara kekudusan hidup dengan membangun relasi yang intim dengan Allah,

10 Gerald O'Collins dan Michael Keenan Jones, "Jesus Our Priest: A Christian Approach to the Priesthood of Christ," Jesus Our Priest: A Christian Approach to the Priesthood of Christ, 2010, 1-328, https://doi.org/10.1093/acprof:oso/9780199576456.001.0001.

11 Sozania Zega dan Hend, "Peranan Dianoia Di Dalam Kekudusan Ditinjau Dari 1 Petrus 1:13-16" 3, no. 2 (2021): 6 .

12 Valentinus Febianto Bayu Kurniawan, "Tinjauan Kekudusan Pelayanan Dari Pelayan Sakramen Yang Berdosa Menurut Santo Agustinus Dari Hippo," Focus 1, no. 2 (2020): 33-40. 
agar dapat menjalankan panggilan dalam menggembalakan domba-domba Kristus.

\section{Kekudusan Dalam Menggembalakan Domba Kristus}

Kekudusan tidak dapat dipisahkan dari kehidupan seorang hamba Tuhan/Imam dalam pelayanan, karena kekudusan akan menjadi sorotan bukan hanya kehidupan pribadi melainkan juga terhadap domba-domba Kristus yang digembalakan. Chrysostom menuliskan bahwa hanya anugerah Tuhan yang dapat mendorong dan memampukan seorang hamba Tuhan dalam menjalankan mandat mulia dari Allah. ${ }^{13}$ Hal tersebut membuat seorang hamba Tuhan/Imam harus benar-benar menghidupi panggilan sebagai wakil Kristus. Seorang hamba Tuhan/Imam senantiasa menjadikan Kristus sebagai dasar penggembalaan, sehingga dapat menuntun domba-domba Kristus kepada kebenaran. Seorang Imam tidak hanya menyenangkan hati umat, melainkan dapat menyeimbangkan teguran yang dapat mengubah setiap pribadi yang digembalakan.

Chrysostom menegaskan bahwa tanggung jawab seorang hamba Tuhan dalam pelayanan ada dua arah, yaitu: dirinya sendiri dan jemaat yang digembalakan. ${ }^{14}$ Terkait hal tersebut Hendi menambahkan bahwa seorang gembala perlu memikul tanggung jawab yang besar untuk melayani jemaat Kristus, untuk itu seorang gembala perlu memiliki kerendahan hati dan kemurnian jiwa. ${ }^{15}$ Dengan demikian seorang hamba Tuhan/Imam perlu menjaga kekudusan serta merefleksikan Kristus di dalam kehidupan sehari-hari, baik dalam pelayanan

\footnotetext{
${ }^{13}$ Neville, "John $\{$ Chrysostom\}: $\{$ Six $\}$ books on the priesthood." 7-9

14 Neville,7.

15 Hendi dan Syelin, "Strategi Pelayanan Pastoral Bagi Kaum Awam Menurut Bapa Gereja Gregorius Agung," Fidei: Jurnal Teologi Sistematika dan Praktika 3, no. 1 (2020): 37-61, https://doi.org/10.34081/fidei.v3i1.68.
} 
dan kehidupan praktis sehari-hari, sehingga layak menggembalakan dombadomba Kristus dan menjadi wakil Kristus di dunia.

Penggembalaan seorang hamba Tuhan/Imam tentu tidak terlepas dari godaan bahkan penderitaan. Roy menuliskan bahwa orang percaya kapan saja dapat terjebak dalam dosa meskipun sudah dikuduskan dengan darah Kristus. ${ }^{16}$ Chrysostom menambahkan bahwa jebakan dosa dapat hadir dari segi apa saja dan menyerang siapa saja, tidak tertutup kemungkinan hamba Tuhan dapat terkena godaan dosa. ${ }^{17}$ Bagi seorang hamba Tuhan rintangan memikul salib tidak hanya datang dari luar, melainkan dalam ladang pelayanan pun ada salib yang perlu dipikul dan dirasakan serta tetap menikmati pelayanan tersebut dengan sukacita. Namun bukan situasi dan kondisi yang menjadi visi seorang Hamba Tuhan dalam pelayanan melainkan semangat menggembalakan domba-domba Allah dengan penuh tanggung jawab. Desti menuliskan bahwa seorang hamba Tuhan perlu bersinergi dengan Allah, karena dengan bersinergi dapat memberi pelayanan yang terbaik bagi jemaat dan mampu menghadapi godaan, baik itu perasaan untuk mundur dari pelayanan. ${ }^{18}$ Chrysostom menambahkan bahwa Yesus senantiasa bersama-sama dengan seorang Imam dalam menghadapi segala penderitaan, kesulitan dan godaan dalam dunia pelayanan/penggembalaan. ${ }^{19}$ Selanjutnya George menuliskan bahwa hamba Tuhan perlu memiliki pola pikir yang berfokus mengenalkan Kristus serta melayani kebutuhan domba Kristus dengan sepenuh KRISTEN."

16 Roy Charly H.P. Sipahutar, "REVITALISASI KEKUDUSAN DALAM HIDUP PELAYAN ${ }^{17}$ Neville, "John \{Chrysostom\}: \{Six\} books on the priesthood."7-9

18 Desti Ratna dan Sari Halawa, "Sinergi Pelayan dan Jemaat Tuhan Menurut 1 Korintus $3: 4-9$ " 1407, no. September (2021): 4-9.

${ }^{19}$ Neville, "John \{Chrysostom\}: $\{$ Six $\}$ books on the priesthood. "7-9 
hati. $^{20}$ Dengan demikian hambatan dan kesulitan dalam pelayanan bukanlah alasan untuk mematahkan semangat dalam menuntun jiwa-jiwa kepada Kristus, karena hal tersebut adalah mandat Allah (Mat. 26: 41) yang mulia dan perlu dikerjakan, sehingga kerajaan Allah semakin diperluas dan nama Allah senantiasa dipermuliakan di dunia ini.

Trifena menuliskan bahwa hidup yang bergantung kepada Allah merupakan sikap hati yang mau dibentuk menjadi pribadi yang lebih baik dalam lingkungan maupun penggembalaan. ${ }^{21}$ Oleh karena itu kehidupan seorang hamba Tuhan/Imam senantiasa memuliakan nama Allah dalam penggembalaan. Chrysostom menuliskan bahwa kekudusan yang sesungguhnya dicerminkan melalui relasi yang intim antara orang percaya dengan Allah, sehingga hati jiwa dan pikiran selaras dengan kehendak Tuhan. ${ }^{22}$ Selanjutnya Siska menuliskan bahwa orang percaya sebagai manusia baru di dalam Kristus senantiasa melengkapi diri dengan kebajikan-kebajikan rohani sehingga merefleksikan kekudusan ilahi. ${ }^{23}$ Seorang hamba Tuhan dan para jemaat senantiasa berjuang untuk lulus uji (tantangan dan godaan) sehingga mencapai tingakat kekudusan yang tinggi, yaitu manunggal dengan Tritunggal. Joseph Cardinal Ratzinger menegaskan bahwa tujuan akhir hidup orang percaya adalah mencapai kesatuan yang sempurna dengan Kristus dan saat yang sama masuk dalam kesatuan hidup bersama Allah sehingga Allah menjadi segala-galanya dalam hidup manusia. ${ }^{24}$ Dengan demikian, seorang hamba Tuhan yang dipilih menjadi wakil Kristus di

20 George P. Fletcher, Glory and Guilt in the Age of Terrorism PRINCETON, vol. 53, 2013.

21 Iva Trifena dkk., "Sikap Hidup Hamba Tuhan Berdasarkan 2 Timotius 2: 1-13" 1407, no. November 2020 (2021): 1-13.

22 Neville, "John Chrysostom: Six books on the priesthood."7-9

23 Fransiska Juliawati dan Hendi Hendi, "Konsep Manusia Baru Menurut Kolose 3:1-4," BONAFIDE: Jurnal Teologi dan Pendidikan Kristen 2, no. 1 (2021): 134-47, https://doi.org/10.46558/bonafide.v2i1.61.

24 Peter John Mcgregor, "Heart to Heart: The Spiritual Christology of Joseph Ratzinger," 2013. 
bumi perlu mengutamakan kehidupan spiritualitas dengan melakukan disiplin rohani melalui tuntunan Roh Kudus, sehingga memiliki kehidupan yang semakin kudus di dalam Tuhan dan layak menjadi wakil Kristus. Terkait konsep tersebut ada kisah St. Theodora dari Aleksandria yang dituduh melakukan kejahatan (memperkosa) yang tidak dilakukan, tetapi dengan kerendahan hati Theodora menerima semua tuduhan tersebut. ${ }^{25}$ Para pemimpin atau hamba Tuhan dapat meneladani kisah hidup para saint (pahlawan iman) yang memiliki kerendahan hati dan juga kekudusan dalam hidup mereka, khususnya dalam menggenapi panggilan mereka sebagai pahlawan iman dan juga kegigihan untuk mencapai Theosis dan cintanya kepada Allah. Maka dalam memenuhi panggilan sebagai hamba Tuhan sikap mencintai Allah adalah kualifikasi penting.

Imam yang mengandalkan Allah senantiasa dimampukan untuk menghadapi segala penderitaan dan mengerjakan tugas mulia sebagai wakil Kristus dengan baik. Memberikan teladan hidup kepada umat yang digembalakan dengan terus memelihara kekudusan hidup serta menanamkan nilai-nilai kebenaran kepada domba-domba Kristus. Dengan demikian kehidupan seorang Imam serta jemaat semakin bertumbuh di dalam Kristus. Karena hamba Tuhan/Imam menyatakan kekudusan penggembalaan bukan hanya secara status melainkan tindakan nyata yang penuh kasih kepada domba-domba gembalaan.

\section{Memelihara Kekudusan Hidup Melalui Disiplin Rohani}

Kekudusan dalam memegang jabatan mulia sebagai seorang hamba Tuhan/Imam memang sangat diperhitungkan terlebih dalam penggembalaan. Sebagai wakil Kristus di bumi seorang Imam senantiasa memelihara kekudusan.

25 "Venerable Theodora of Alexandria - Orthodox Church in America," diakses 28 Agustus 2021, https://www.oca.org/saints/lives/2017/09/11/102570-venerable-theodora-of-alexandria. 
Chrysostom mengatakan bahwa seorang hamba Tuhan/Imam termasuk orang percaya sangat rentan jatuh dalam dosa untuk itu perlu senantiasa membangun relasi dengan Allah dan terus mengerjakan latihan-latihan rohani. Latihan atau disiplin rohani yang dimaksud adalah seperti doa puja Yesus dan pertobatan yang disertai air mata (penyesalan) dengan iman kepada Yesus Kristus. Ada dua disiplin rohani yang perlu dikerjakan oleh seorang hamba Tuhan/Imam serta domba-domba yang digembalakan, yaitu: pertama, doa Puja Yesus. Berdoa merupakan latihan rohani yang sangat melekat dalam kehidupan manusia termasuk orang percaya. Manusia tahu cara berdoa tetapi kadang keliru memahami makna doa, dimana kebanyakkan manusia, termasuk orang percaya seringkali berdoa hanya saat genting dan hanya saat ingat untuk berdoa. Pada zaman yang serba cepat ini banyak orang memiliki kesibukan masing-masing dan terkadang lebih mengutamakan kebutuhan jasmani dibandingkan rohani. Doa mencerminkan kedekatan atau relasi yang semakin mengeratkan sebuah hubungan. Bagi orang percaya doa sarana relasi dengan Allah, maka diperlukan sikap hati yang benar dihadapan Tuhan.

Seorang hamba Tuhan perlu terus menerus menerapkan doa puja Yesus. Dengan doa puja Yesus tanpa henti maka hati, pikiran dan jiwa senantiasa dapat fokus dan tertuju kepada Allah di dalam keheningan. Hendi dan Alda menuliskan hesychia adalah puncak dari semua latihan rohani yang utama untuk mencapai kebajikan-kebajikan jiwa (termasuk kekudusan), yaitu melatih roh (askesis), pemurnian (purifikasi), fokus kepada Allah (nous), berjaga-jaga (nepsis), keheningan batin (silence), pengendalian diri, ketersapihan nafsu (apatheia) dan 
kasih $(e r o s) .{ }^{26}$ Ketika Doa ini dengan sungguh-sungguh diterapkan maka pikiran Kristuslah yang memenuhi hati dan pikiran kita bukan logismoi (pikiran jahat). Tuhan memang tidak dapat dilihat dengan mata jasmani tetapi dengan mata rohani, melalui doa dalam batin dan minta tuntunan roh kudus. Untuk memperoleh kekudusan dibutuhkan askesis, melatih diri menguasai kedagingan sehingga logismoi tidak menguasai tubuh.

Bapa gereja St. Theophan the Recluse menuliskan bahwa ketika berdoa mintalah tanpa henti belas kasihan Allah. ${ }^{27}$ Ketika berdoa tujuan kita bukan memenuhi keegoisan kita melainkan mengalami kepenuhan di dalam Allah dengan pertobatan serta kerendahan hati sehingga tubuh hati, roh dan jiwa kita diarahkan untuk memuliakan Allah serta melawan segala macam keinginan duniawi. Terkait hal tersebut Hisikia menuliskan bahwa sumber pertolongan sesungguhnya hanya dari Allah, dengan doa puja Yesus kehidupan orang percaya semakin diarahkan kepada Kristus Yesus. ${ }^{28}$ Doa yang sungguh-sungguh dapat mengubah pribadi pendoa tersebut. Alkitab memberikan contoh mengenai doa seorang pemungut cukai (Luk. 18: 10-13). Dengan demikian doa dalam keheningan akan semakin memperlengkapi orang percaya untuk senantiasa memiliki hati yang rindu dan jiwa yang haus kepada Allah sehingga saling bersinergi dan dituntun dalam kebenaran ilahi. Chrysostom menegaskan bahwa seorang Imam/hamba Tuhan dipakai Allah untuk menuntun jiwa-jiwa jemaat

\footnotetext{
26 Hendi \& Geralda Aprillia Salindeho, "Hesychia Menurut Bapa-bapa Padang Gurun dan Delapan Kebajikan Jiwa," Jurnal Teologi "Cultivation" 4, no. 2 (2020): 111-31.

${ }_{27}$ Hendi, Inspirasi Batin 1, Journal of Chemical Information and Modeling (Yogyakarta: LeutikaPrio, t.t.).

${ }^{28}$ Hisikia Gulo dan Hendi Hendi, "Spiritualitas Doa Puja Yesus Menurut Bapa-Bapa Philokalia," Manna Rafflesia 7, no. 2 (2021): 327-47, https://doi.org/10.38091/man_raf.v7i2.151.
} 
kepada jalan kebenaran. ${ }^{29}$ Bapa gereja St. Philotheos mengatakan bahwa doa puja Yesus dapat menarik perhatian Allah. ${ }^{30}$ Hal yang sama juga dikatakan oleh St. Hesychios bahwa Allah hadir dan menaungi pada saat hati dan pikiran berpusat kepada-Nya melalui doa puja Yesus. ${ }^{31}$ Dengan demikian Doa puja Yesus merupakan salah satu metode penting dalam aspek kehidupan orang percaya, khususnya seorang hamba Tuhan sebagai reflektor Allah terhadap umat gembalaan.

Kedua, pertobatan yang sungguh-sungguh kepada Allah sebagai cerminan hidup pertobatan yang nyata. Foriaman menuliskan bahwa pertobatan perlu melekat dan menjadi gaya hidup dalam kehidupan orang percaya sebagai gambar dan rupa Allah. ${ }^{32}$ Chrysostom juga menekankan bahwa pertobatan bukan hanya bersifat semu atau sementara melainkan harus senantiasa diperbaharui untuk mencapai pemurnian. ${ }^{33}$ Dengan demikian doa dan pertobatan serta penyesalan harus diselaraskan sehingga orang percaya menyadari bahwa hanya satu Pribadi yaitu Yesus Kristus yang dapat memperbaharui serta memurnikan jiwa. Bentuk pertobatan yang sederhana dan praktis adalah pengendalian diri, terus nepsis (berjaga-jaga), tekun memuji Allah dan berdoa. Hal tersebut akan menguduskan jiwa orang percaya. Sebagai orang percaya yang telah menerima anugerah dari Tuhan perlu senantiasa mencerminkan Kristus dalam kehidupan, Salah satunya terus meminta belas kasihan Allah melalui pertobatan yang sungguh-sungguh dihadapan Allah.

${ }^{29}$ Neville, "John Chrysostom: Six books on the priesthood."7-9"

30 Hendi, Inspirasi Batin 1.

31 Hendi.

32 Foriaman Zega dan Hendi H, "Konsep Pertobatan Menurut 2 Korintus 7: 8-11," Jurnal Teologi Cultivation 4, no. 1 (25 Juli 2020): 30-43, https://doi.org/10.46965/JTC.V4l1.215.

${ }^{33}$ Neville, "John \{Chrysostom\}: \{Six\} books on the priesthood." 
Orang percaya dapat mengungkapkan pujian, harapan bahkan ucapan syukur kepada Allah. Selain sikap hati yang benar dihadapan Allah, air mata juga dapat mencerminkan kesungguhan seorang yang menaikan doa kepada Allah sebagai bentuk pertobatan dan penyesalan. Air mata dapat menyimbolkan bahwa seseorang secara totalitas membawa pengakuan kepada Allah dengan penuh kerendahan hati, mengakui bahwa sangat membutuhkan Allah dalam kehidupan. St. Hesychios menuliskan bahwa antara doa puja Yesus dan Nepsis (berjaga-jaga) perlu saling bersinergi, sehingga menguatkan satu sama lain. Ketika batin berdoa tanpa henti maka nous terus berjaga-jaga agar terhindar dari segala pikiran jahat. ${ }^{34}$ Selanjutnya St. Yohanes Climacus menuliskan bahwa pengakuan dosa melalui tetesan air mata di dalam doa tidak sepenuhnya menyucikan seseorang dari perbuatan dosa, sebab bukan hanya baptisan jasmani melainkan baptisan air mata yang dilengkapi dengan belas kasihan Allah sehingga menyucikan serta menyelamatkan jiwa manusia, inilah yang disebut pembaptisan kekal. ${ }^{35}$ Oleh sebab itu segala perbuatan di dunia perlu dipertanggungjawabkan bukan hanya dihadapan manusia melainkan juga dihadapan Allah dengan penuh keberanian dalam kekekalan bersama-Nya.

Air mata pertobatan yang sungguh-sungguh dapat mengubah seseorang untuk berbalik dari perbuatan jahat. Hendi menekankan bahwa ratapan dan

34 Hendi, Inspirasi Batin 1.

35 St. John Climacus mengatakan bahwa gereja juga mengakui adanya pertobatan air pembaptisan dan air mata pertobatan. Ada dua kali baptisan yang dialami oleh orang percaya yaitu baptisan pertama adalah percik/lahiria (baru lahir/masih bayi) dan kedua adalah baptisan air mata yang disertai penyesalan dosa (Allah mensucikan manusia dari dosa dan dilayakkan untuk masuk dalam kerajaan-Nya). Alkitab memberikan contoh yaitu Petrus yang menerima baptisan kedua berupa pengampunan dan keselamatan kekal dari Yesus atas penyesalan dan pengakuannya yang tulus di hadapan Tuhan. Ketika orang percaya sebagai manusia berdosa menyerahkan diri sepenuhnya kepada Allah la akan senantiasa dimurnikan dan disucikan melalui baptisan kedua sebagai manusia baru yang layak masuk dalam kerajaan sorga. (Lih. Coniaris, x.), Bdk. Anthony M. Coniaris, Philokalia: The Bible of Orthodox Spirituality (Minneapolis: Light\&Life Publishing Company, 1998). 
tangisan yang lahir dari hati kepada Allah dapat mengembalikan kesucian pikiran yang telah dicemari dosa. ${ }^{36}$ Dengan demikian air mata pertobatan merupakan wujud nyata yang mewakili penyesalan yang begitu dalam yang diungkapkan melalui doa kepada satu Pribadi yang hidup yaitu Yesus sumber keselamatan kekal. St. Symeon menuliskan bahwa air mata pertobatan dapat memulihkan seseorang dari perbuatan dosa yang dilakukannya. ${ }^{37}$ Chrysostom juga mengatakan bahwa air mata pertobatan tidak hanya memulihkan melainkan dapat membersihkan pikiran dan jiwa seseorang dari belenggu dosa. ${ }^{38}$ Oleh karena itu orang percaya senantiasa meneladani pribadi Yesus yang telah menyerahkan diri secara totalitas, hal itu terbukti ketika Yesus berdoa di taman getsemani kepada Bapa. Air mata Yesus menghadirkan suasana yang begitu hidup bagi dunia, salah satunya ketika Yesus menangisi kematian saudara ibunya yaitu Lazarus. Oleh sebab itu pentingnya seorang hamba Tuhan sebagai wakil Allah di dunia untuk senantiasa menguduskan hati, jiwa dan pikiran, sehingga dituntun ke jalan yang dikehendaki-Nya. Chrysostom mengatakan bahwa perjalanan seorang hamba Tuhan dalam melayani domba-domba Kristus akan selalu dipenuhi dengan berbagai hambatan bahkan pencobaan, namun kuasa kemuliaan yang Allah berikan akan semakin mendorong hamba Tuhan untuk semakin mempertahankan kekudusannya di hadapan-Nya. ${ }^{39}$ Ketika orang percaya menyesali setiap perbuatan dosanya dan menaruh harapan sepenuhnya kepada Tuhan melalui kerendahan hati dan berseru kepada Tuhan, maka spiritualitasnya semakin bertumbuh, karena mengalami perjumpaan pribadi dengan Tuhan. Hendi

36 Hendi, "Pertobatan Di dalam Philokalia: Artikel Ulasan," Dunamis: Jurnal Teologi dan Pendidikan Kristiani 3, no. 1 (2018): 52-73.

${ }^{37}$ Coniaris, Philokalia: The Bible of Orthodox Spirituality, $\mathrm{x}$.

38 Coniaris.

39 Neville, "John \{Chrysostom\}: $\{$ Six $\}$ books on the priesthood."7-9 
menuliskan Tuhan tidak hanya memberikan pengampunan atas kesungguhan pertobatan melalui air mata dihadapan-Nya melainkan menggantikan segala segi dosa dengan anugerah kekekalan. Dengan kata lain anugerah Allah dan belas kasihan Allah yang bekerja di balik air mata pertobatan.

Para hamba Tuhan wajib menerapkan dua disiplin doa puja Yesus dan pertobatan. Dengan dua disiplin rohani tersebut maka seorang hamba Tuhan semakin memfokuskan diri dalam penggembalaan, sebab menjadikan Kristus sebagai pusat utama. Meskipun banyak kesulitan yang dihadapi, tetapi hamba Tuhan harus melangkah dan menghidupi kebenaran yang kemudian diajarkan kepada jemaat (lewat pemberitaan Firman Tuhan) sebab pelayanan menjadi hamba Tuhan memiliki wibawa tetapi sekaligus pelayanan memikul salib (tanggung jawab) yaitu menuntun jiwa-jiwa kepada Kristus serta hidup dalam kekudusan.

\section{KESIMPULAN}

Kekudusan memiliki nilai yang sangat penting dalam kehidupan seorang hamba Tuhan/Imam dalam berbagai aspek. Kekudusan dalam jabatan sebagai wakil Kristus, kekudusan dalam penggembalaan serta mendisiplinkan kekudusan hidup melalui latihan/disiplin rohani (doa dan pertobatan). Jabatan Imam tidak diberikan kepada sembarangan orang melainkan hanya orang-orang yang dikhususkan Allah kemudian ditentukan melalui sistem atau organisasi gereja seperti zaman sekarang ini. Calon Imam harus melewati berbagai seleksi untuk dapat lolos menjadi seorang Imam atau hamba Tuhan. Gereja memiliki peran yang sangat penting dalam mengukuhkan calon Imam. Imam merupakan pekerjaan yang mulia karena khusus sebagai wakil Kristus, namun juga sangat 
berat karena ada salib yang dipikul. Imam bertanggung jawab untuk menuntun domba-domba Kristus kepada jalan keselematan. Seorang Imam layak mempersembahkan korban persembahan kepada Allah di atas Altar yang kudus. Imam senantiasa menguji kemurnian hati, pikiran dan jiwanya sehingga Ia dimampukan oleh Roh Kudus untuk melewati setiap tantangan, godaan bahwa penderitaan sama seperti Kristus yang mengalami penderitaan untuk menuju kemuliaan. Teologi kekudusan John Chrysostom perlu diterapkan oleh para hamba Tuhan, yaitu disiplin rohani melalui doa puja Yesus dan Pertobatan yang sungguh-sungguh kepada Kristus (penyesalan dosa). Dengan disiplin rohani seorang Imam semakin melatih dan mengontrol keinginan, kehendak dan kekudusan hidup serta menuntun domba-domba Kristus kepada jalan kebenaran.

\section{DAFTAR PUSTAKA}

Abdillah, Leon. "Bahan dan Metode Artikel Ilmiah (Material and Methods of Scientific Articles)." Menulis Artikel Ilmiah untuk Publikasi (Writing Scientific Papers for Publications). Medan: Yayasan Kita Menulis, 2020.

Anggu, Peter. "Pertumbuhan Karakter Kristen 'Kepribadian Seorang Pelayan."” Jurnal Jaffray 3, no. 1 (2005): 26. https://doi.org/10.25278/jj71.v3i1.138.

Cahyani, Eka Nur, dan Hendi Hendi. "Kemuliaan Jabatan Seorang Imam Menurut John Chrysostom." Fidei: Jurnal Teologi Sistematika dan Praktika 4, no. 1 (2021): 99-116. https://doi.org/10.34081/fidei.v4i1.171.

Coniaris, Anthony M. Philokalia: The Bible of Orthodox Spirituality. Minneapolis: Light\&Life Publishing Company, 1998.

George P. Fletcher. Glory and Guilt in the Age of Terrorism PRINCETON. Vol. 53, 2013.

Gulo, Hisikia, dan Hendi Hendi. "Spiritualitas Doa Puja Yesus Menurut BapaBapa Philokalia." Manna Rafflesia 7, no. 2 (2021): 327-47. https://doi.org/10.38091/man_raf.v7i2.151. 
Hadiwitanto, Handi. "Metode Kuantitatif dalam Teologi Praktis." GEMA TEOLOGIKA 2, no. 1 (28 April 2017): 1. https://doi.org/10.21460/gema.2017.21.291.

Hendi. Inspirasi Batin 1. Journal of Chemical Information and Modeling. Yogyakarta: LeutikaPrio, t.t.

"Pertobatan Di dalam Philokalia: Artikel Ulasan." Dunamis: Jurnal Teologi dan Pendidikan Kristiani 3, no. 1 (2018): 52-73.

Hendi \& Geralda Aprillia Salindeho. "Hesychia Menurut Bapa-bapa Padang Gurun dan Delapan Kebajikan Jiwa." Jurnal Teologi "Cultivation” 4, no. 2 (2020): 111-31.

Hendi dan Syelin. "Strategi Pelayanan Pastoral Bagi Kaum Awam Menurut Bapa Gereja Gregorius Agung." Fidei: Jurnal Teologi Sistematika dan Praktika 3, no. 1 (2020): 37-61. https://doi.org/10.34081/fidei.v3i1.68.

Jihole, Deswita S. "Makna Kemuliaan Seorang Imam Menurut Artikel ini adalah sebuah ulasan mengenai makna kemuliaan seorang imam menurut pandangan Yohanes Krisostomus dalam bukunya yang berjudul Six Books on the Priesthood. Yaitu sebuah buku spiritual yang ditulis sendiri ol" 4, no. 2 (2020): 70-83.

Juliawati, Fransiska, dan Hendi Hendi. "Konsep Manusia Baru Menurut Kolose 3:1-4." BONAFIDE: Jurnal Teologi dan Pendidikan Kristen 2, no. 1 (2021): 134-47. https://doi.org/10.46558/bonafide.v2i1.61.

Kurniawan, Valentinus Febianto Bayu. "Tinjauan Kekudusan Pelayanan Dari Pelayan Sakramen Yang Berdosa Menurut Santo Agustinus Dari Hippo.” Focus 1, no. 2 (2020): 33-40.

Mangean, Astin. "Pendekatan Historis Kristis Terhadap Bilangan 3 dan 4 tentang Tanggung Jawab Pendeta." BIA': Jurnal Teologi dan Pendidikan Kristen Kontekstual 2, no. 2 (2019): 209-22. https://doi.org/10.34307/b.v2i2.133.

Mcgregor, Peter John. "Heart to Heart: The Spiritual Christology of Joseph Ratzinger," 2013.

Neville, Graham. "John $\{$ Chrysostom $\}:\{$ Six $\}$ books on the priesthood," 1964, 150 .

O'Collins, Gerald, dan Michael Keenan Jones. "Jesus Our Priest: A Christian Approach to the Priesthood of Christ." Jesus Our Priest: A Christian Approach to the Priesthood of Christ, 2010, 1-328. https://doi.org/10.1093/acprof:oso/9780199576456.001.0001.

Ratna, Desti, dan Sari Halawa. "Sinergi Pelayan dan Jemaat Tuhan Menurut 1 Korintus 3 : 4-9" 1407, no. September (2021): 4-9. 
Roy Charly H.P. Sipahutar. "Revitalisasi Kekudusan Dalam Hidup Pelayan Kristen" 2 (2018): 2.

Santoso, Dwi Setio Budiono. "Peran Khotbah Gembala Sidang dalam Pertumbuhan Rohani Jemaat." MAGNUM OPUS: Jurnal Teologi dan Kepemimpinan Kristen 1, no. 2 (2020): 88-97. https://doi.org/10.52220/magnum.v1i2.39.

Sozania Zega dan Hend. "Peranan Dianoia Di Dalam Kekudusan Ditinjau Dari 1 Petrus 1:13-16" 3, no. 2 (2021): 6.

Trifena, Iva, Mayrina Wokas, Sekolah Tinggi, Teologi Injil, dan Bhakti Caraka. "Sikap Hidup Hamba Tuhan Berdasarkan 2 Timotius 2 : 1-13" 1407, no. November 2020 (2021): 1-13.

"Venerable Theodora of Alexandria - Orthodox Church in America." Diakses 28 Agustus 2021. https://www.oca.org/saints/lives/2017/09/11/102570venerable-theodora-of-alexandria.

Zaluchu, Sonny. "Penderitaan Kristus Sebagai Wujud Solidaritas Allah Kepada Manusia." DUNAMIS: Jurnal Penelitian Teologi dan Pendidikan Kristiani 2, no. 1 (4 November 2017): 61. https://doi.org/10.30648/dun.v2i1.129.

Zega, Foriaman, dan Hendi H. "Konsep Pertobatan Menurut 2 Korintus 7: 8-11." Jurnal Teologi Cultivation 4, no. 1 (25 Juli 2020): 30-43. https://doi.org/10.46965/JTC.V4I1.215. 